\title{
Relationship between oxidative stress markers and cardiac syndrome $X$
}

\author{
Oksidatif stres belirteçleri ile kardiyak sendrom X arasındaki ilişki
}

\author{
Durmuş Yıldıray Şahin, Zafer Elbasan, Mustafa Gür, Caner Türkoğlu, Betül Özaltun, Zehra Sümbül, Murat Çaylı \\ Numune Education and Research Hospital, Dept. Cardiology, Adana, Turkey
}

\section{ABSTRACT}

Objectives: To investigate the alterations of oxidative and antioxidative status in patients with cardiac syndrome $X(C S X)$.

Materials and methods: Thirty-three patients with CSX (CSX group), 27 patients without CSX (NSX) and 20 healthy volunteers as control group were included into the study. Oxidative status of serum was evaluated by measuring total oxidant status (TOS), lipid hydroperoxide levels (LOOH) and oxidative stress index (OSI) of serum, and antioxidative status of serum was evaluated by measuring total antioxidant capacity (TAC). Also, hsCRP and other biochemical markers were measured in all subjects.

Results: The oxidants (TOS, LOOH and OSI) and CRP levels were higher, and TAC was lower in the patients with CSX than NSX group and control group. Also, the oxidants (TOS, LOOH and OSI) and hsCRP levels, a marker of chronic inflammation, were higher, and TAC was lower in the patients with NSX than control group. In addition, in patients with CSX, a significant positive correlation ( $=0.606, p<0.001$ ) was found between the OSI level and ST depression.

Conclusion: Oxidants increased and antioxidants decreased, namely oxidative/antioxidative balance shifted to oxidative stress in patients with CSX. Thus, oxidative stress may have a role in the etiopathogenesis of the disease. J Clin Exp Invest 2012; 3(2): 174-180

Key words: Oxidative stress, oxidant, antioxidant, cardiac syndrome $\mathrm{X}$

\section{INTRODUCTION}

Cardiac syndrome $X(C S X)$ is a clinical entity characterized by typical chest pain that is often prolonged in duration, normal coronary arteries as assessed by coronary angiography, non-inducible coronary vasospasm with ergonovine provocation and ST segment depression on treadmill exercise testing. ${ }^{1-3}$ Patients with CSX represent a heterogeneous syndrome, which encompasses different

\section{ÖZET}

Amaç: Biz bu çalışmada kardiyak sendrom X'li (CSX) hastalarda oksidatif ve antioksidatif durumlardaki değişimi araşıırdık.

Gereç ve yöntem: Çalışmamıza 33 CSX'li hasta, 27 CSX tanısı olmayan (NSX) hasta ve kontrol grubu olarak 20 sağlıklı gönüllüyü dahil ettik. Serumun oksidatif durumu total oksidan durum (TOS), lipid hidroperoksid seviyesi $(\mathrm{LOOH})$ ve serum oksidatif stres indeksi ölçülerek (OSi) değerlendirildi. Serumun antioksidatif durumu ise total antioksidan kapasite (TAC) ölçülerek değerlendirildi. Ayrıca tüm vakalarda hsCRP ve diğer biyokimyasal belirteçler ölçüldü.

Bulgular: CSX grubunda NSX ve kontrol grubuna göre oksidan seviyeleri (TOS, LOOH ve OSI) ve CRP seviyeleri daha yüksekken, TAC seviyeleri daha düşük bulundu. Ayrıca NSX grubunda kontrol grubuna göre oksidanlar (TOS, $\mathrm{LOOH}$ ve OSI) ve kronik enflamasyonun bir belirteci olan hsCRP seviyeleri daha yüksekken TAC seviyeleri daha düşük olarak saptandı. Bunlara ek olarak CSX'li hastalarda OSI seviyesi ve ST depresyonu arasında istatistiksel olarak anlamlı bir korelasyon mevcuttu $(r ; 0.784$, $\beta=0,606, p<0,001$ ).

Sonuç: CSX'li hastalarda oksidanlarda artış antioksidanlarda düşüş yani oksidatif -antioksidatif dengede oksidatif stres yönüne kayış görülmektedir. Bundan dolayı oksidatif stres bu sendromun patogenezinde rol oynayan bir faktör olabilir.

Anahtar kelimeler: Oksidatif stres, oksidan, antioksidan, kardiyak sendrom $X$.

pathogenic mechanisms. Microvascular damage of coronary bed has been considered the main pathogenesis factor and it may induce the onset of CSX eventually associated with other metabolic and hemodynamic parameters. An impaired endothelium depending on the dilation of the coronary resistance vessels has also been found in these patients, and supposed to play an important role..$^{4-6}$ Microvascular dysfunction, which is the main pathogenesis factor 
in CSX, is associated with oxidative stress or proinflammatory cytokine levels. ${ }^{7,8}$ Also, patients with CSX include many conditions concerned with oxidative stress such as ischemia, ${ }^{9,10}$ inflammation, ${ }^{11,12}$ endothelial dysfunction ${ }^{13}$ and depression. ${ }^{14}$

Reactive oxygen species are produced in metabolic and physiological processes, and harmful oxidative reactions may occur in organisms that remove them via enzymatic and non-enzymatic antioxidative mechanisms. Increases in oxidants and decreases in antioxidants cannot be prevented, and the oxidative/antioxidative balance shifts towards the oxidative status, which has been implicated in over 100 disorders, develops. ${ }^{15}$ Clinical and experimental studies have shown that oxidative stress and lipid peroxidation are involved in pathogenesis of atherosclerosis. ${ }^{16}$ Also, previous studies have demonstrated that antioxidant therapy has beneficial effects on atherosclerosis progression, ${ }^{17}$ but there are some trials that have demonstrated opposite findings. ${ }^{18,19}$ However, in CSX, effect of oxidative status and antioxidant therapy has not been assessed in detail so far.

There is only one published data investigating the relationship between CSX with oxidative stress. ${ }^{12}$ However, in that study, oxidative and antioxidative balance was not completely investigated in patients with CSX, only total antioxidant capacity (TAC) was investigated, and other indicator parameters such as oxidative stress index (OSI), total oxidant status (TOS), and lipid hydroperoxide ( $\mathrm{LOOH})$ levels had not been investigated. On the other hand, there is no published data indicating whether there is a relationship between exercise ST depression and oxidative stress parameters.

In this study, oxidative and antioxidative status and their relationships with exercise ST depression and high sensitive CRP (hsCRP) levels were investigated in patients with CSX and compared with NSX patients and healthy controls.

\section{MATERIALS AND METHODS}

\section{Subjects}

Three groups of subjects, matched for gender and age, were studied. The first group consisted of 33 consecutive patients with cardiac CSX (CSX group) who had: a diagnosis of typical CSX (i.e., typical effort angina, ST segment depression during exercise stress test, totally smooth coronary arteries at angiography). The second group (Non SX group= NSX) consisted of 27 consecutive patients, similar in gender and age to the SX group, who had experienced atypical chest discomfort, negative treadmill tests and normal coronary angiograms, and whom they were evidenced no signs of vasospastic angina. The third group consisted of 20 healthy volunteers (control group). These subjects were enrolled from the nonmedical staff of our hospital or their relatives and were selected to match the CSX group by gender and age. For inclusion into the control group, subjects had to have no known coronary risk factor and cardiac symptoms, and should have normal electrocardiographic and echocardiographic examinations, and negative exercise stress tests. Coronary angiography was not performed in this group.

Exclusion criteria were the presence of neoplastic disease, recent major surgical procedure, diuretic, antioxidant drugs, niacin and statins, vitamin and alcohol use, smoking, concomitant inflammatory diseases such as infections and autoimmune disorders, and liver or kidney disease. Patients suffering from organic coronary artery disease (CAD), vasospastic angina, heart failure, hypertensive heart disease with left ventricular hypertrophy, valvular heart disease, idiopathic hypertrophic and dilated cardiomyopathy were also excluded from the study. The Local Ethics Committee approved the study protocol. Informed consent for participation in the study was obtained from all individuals.

\section{Baseline definitions and measurements}

The criteria for CSX included the typical exertional chest pain, a positive treadmill exercise test, and a normal coronary angiogram. None of the patients exhibited any irregularities on coronary angiograms. Typical angina pectoris was defined as an exerciseinduced retrosternal chest pain, which could be relieved by either rest or the sublingual administration of nitroglycerin. Hypertension (HT) was defined as a diastolic blood pressure $\geq 90 \mathrm{mmHg}$, systolic blood pressure $\geq 140 \mathrm{mmHg}$ or self-reported use of an antihypertensive drug. Diabetes mellitus (DM) was diagnosed if the fasting plasma glucose concentration was $\geq 126 \mathrm{mg} / \mathrm{dl}$ on two separate occasions or if the patient was treated with insulin or oral hypoglycemic agents. A family history of CAD was defined as a history of sudden death, myocardial infarction, coronary angioplasty or coronary artery bypass graft surgery in a first-degree male relative younger than 55 years old or a female relative younger than 65 years old. Body mass index (BMI) was computed as weight divided by height squared $\left(\mathrm{kg} / \mathrm{m}^{2}\right)$.

Plasma triglyceride, total cholesterol, low density lipoprotein (LDL), high density lipoprotein (HDL) concentrations and fasting glucose were measured by automated chemistry analyzer (Abbott, Aeroset) by using commercial kits (Abbott, USA). The plasma 
levels of hsCRP were measured immediately on the otoanalyser (Aeroset, Abbott) by spectrophotometric commercial kit (Scil Diagnostics $\mathrm{GmbH}$, USA).

\section{Blood sampling protocol}

Peripheral venous blood samples were taken into tubes in the fasting state in all subjects. Blood samples were centrifuged at $3000 \mathrm{rpm}$ for $10 \mathrm{~min}$, and serum was separated. The samples were run immediately or stored (for oxidative stress parameters) at $-80^{\circ} \mathrm{C}$ until analysis.

\section{Treadmill exercise stress testing}

All treadmill exercise tests were conducted in the morning (CASE Marquette 12, Marquette Electronics, Milwaukee, WI, USA). Three ECG leads (V2, $\mathrm{V} 5$ and aVF) were continuously monitored during these tests. Bruce protocol was used during tests. A standard 12-lead ECG was printed, and blood pressure was measured (via cuff sphygmomanometer) at baseline, at the end of each stage, and at peak exercise, as well as at the onset of chest pain and/ or significant ST segment depression. Total exercise times were recorded in all cases. Electrocardiographic recovery was also continuously monitored, until the depressed ST segment returned to baseline levels. A positive treadmill test was defined by the occurrence of ischemic ST segment depression ( $\geq 1.0 \mathrm{~mm}$ horizontal or downsloping depression at $80 \mathrm{~ms}$ from the $\mathrm{J}$ point) during treadmill exercise, as measured by several leads on the ECG (usually II, III, aVF, V3-6). ST depression at peak exercise was determined in the electrocardiographic lead that demonstrated maximal depression versus baseline. This was automatically measured at $80 \mathrm{~ms}$ after the $\mathrm{J}$ point by treadmill automated measurement method.

\section{Assessment of coronary arteries by coronary angiography}

In all individuals in the groups of CSX and NSX, coronary angiography was performed by using the Siemens Angioscop X-ray (Siemens Artis zee, Siemens Healtcare, Muenchen, Germany) and using standard Judkins technique. Angiograms were performed for the investigation of ischemic heart disease based on clinical indications (typical and atypical chest discomfort or abnormal stress test result). Two experienced cardiologists, unaware of the patients' clinical characteristics and biochemical results, reviewed all the angiographic images.

\section{Measurement of total antioxidant capacity (TAC)}

TAC of serum, taken before and 5-10 minute after the angiography procedure was determined using a novel automated measurement method, developed by Erel. ${ }^{20-22}$ In this method, hydroxyl radical, which is the most potent biological radical, is produced. In the assay, ferrous ion solution, which is present in the Reagent 1 , is mixed by hydrogen peroxide, which is present in the Reagent 2 . The sequential produced radicals such as brown colored dianisidinyl radical cation, produced by the hydroxyl radical, are also potent radicals. In this assay, antioxidative effect of the sample against the potent free radical reactions, which is initiated by the produced hydroxyl radical, is measured. The assay has got excellent precision values, which are lower than $3 \%$. The results are expressed as mmol Trolox equivalent/l.

\section{Measurement of total oxidant status (TOS)}

TOS values of the samples were measured by a most recently developed automated method. ${ }^{23}$ In this method, hydrophylic and lipophylic oxidants oxidize ferrous ion to ferric ion. ${ }^{24}$ The oxidation reaction is enhanced by using glycerol and the produced ferric ion makes a stable colored complex with xylenol orange, a ferric dye. Hydrogen peroxide solution is used as assay standards. The assay has got an excellent $\mathrm{CV} \%$ values, less than $3 \%$.

\section{Measurement of lipid hydroperoxide}

Lipid hydroperoxide level of serum was measured an automated method by using xylenol orange. ${ }^{25}$ The method is based on a known principle of the oxidation of Fe II to Fe III by lipid hydroperoxides, under acidic conditions.

\section{Oxidative stress index}

The percent ratio of the TOS to the TAC gave the OSI, an indicator of the degree of oxidative stress [(TOS/TAC) $\times 100] .{ }^{21,22,26}$

\section{Statistical analyses}

Results are presented as mean \pm SD or frequency expressed as a percent. Categorical variables were compared by using chi-square test. Comparison among multiple groups was performed by oneway analysis of variance (ANOVA) with LSD post hoc test for continuous variables. Associations of OSI with demographical, clinical and electrocardiographic parameter were assessed by Pearson correlation coefficient. A 2-tailed $p$ value $<0.05$ was considered statistically significant. Independent relationships of OSI level were assessed by multiple linear regression analysis. Standardized $\beta$ regression coefficients and their significance from multiple linear regression analysis were also reported. 


\section{RESULTS}

The baseline characteristics of the groups are summarized in Table 1. Age, gender, BMI, plasma triglyceride, total cholesterol and LDL cholesterol concentrations, systolic and diastolic blood pressure were similar in all groups ( $p>0.05$ for all). The presentation of conventional risk factors (family history, gender, hypertension, DM) in the CSX group was similar to NSX group ( $p>0.05$ for all). Fasting glucose and HDL cholesterol were similar in CSX and NSX ( $p>0.05$ for both). But, fasting glucose and HDL cholesterol levels of both CSX and NSX group were different from the control group. Mean CRP level of CSX group was higher than both NSX and control group. Also, mean CRP level of NSX group was higher than control group. The mean TOS levels, LOOH levels and OSI levels of CSX group were higher when compared with both NSX and control groups. The mean TOS level and OSI level of NSX group were higher than control group. $\mathrm{LOOH}$ levels were similar in both NSX and control groups. Also, mean TAC level of CSX group was lower when compared with both NSX and control groups. Mean TAC level of NSX group was lower than the control group.

Table 1. Comparison of demographic, clinical and oxidative characteristics of groups

\begin{tabular}{|c|c|c|c|c|}
\hline & Controls $(n=20)$ & CSX group $(n=33)$ & NSX group $(n=27)$ & $p$ value Chi square \\
\hline Male/female & $6 / 14$ & $10 / 23$ & $8 / 19$ & 0.975 \\
\hline Hypertension & - & 12 & 10 & 0.584 \\
\hline DM & - & 11 & 7 & 0.369 \\
\hline Family history & - & 5 & 4 & 0.630 \\
\hline Aspirin use & - & 33 & 25 & 0.192 \\
\hline Nitrate use & - & 14 & 11 & 0.591 \\
\hline B-blocking use & - & 13 & 11 & 0.525 \\
\hline ACE inhibitor use & - & 7 & 6 & 0.560 \\
\hline \multirow[t]{2}{*}{ Oral hypoglycemic agent } & - & 6 & 5 & 0.594 \\
\hline & & & & Anova $p$ \\
\hline Age (years) & $47.9 \pm 4.7$ & $47.0 \pm 5.5$ & $48.7 \pm 4.5$ & 0.472 \\
\hline $\mathrm{SBP}(\mathrm{mmHg})$ & $113.7 \pm 7.7$ & $122.2 \pm 20.6$ & $122.9 \pm 16.7$ & 0.237 \\
\hline $\mathrm{DBP}(\mathrm{mmHg})$ & $72.2 \pm 7.3$ & $76.7 \pm 14.6$ & $77.7 \pm 13.2$ & 0.197 \\
\hline Body mass index $\left(\mathrm{kg} / \mathrm{m}^{2}\right)$ & $27.1 \pm 1.9$ & $26.8 \pm 2.4$ & $26.8 \pm 2.6$ & 0.385 \\
\hline HsCRP (mg/dl) & $0.38 \pm 0.15^{*}$ & $1.06 \pm 0.3^{* *}$ & $0.71 \pm 0.31$ & $<0.001$ \\
\hline Triglyceride (mg/dl) & $147.9 \pm 14.7$ & $155.1 \pm 43.6$ & $135.9 \pm 43.0$ & 0.098 \\
\hline Total cholesterol (mg/dl) & $174.1 \pm 22.3$ & $188.8 \pm 46.8$ & $180.1 \pm 44.8$ & 0.385 \\
\hline LDL (mg/dl) & $102.8 \pm 3.4$ & $122.1 \pm 38.2$ & $116.8 \pm 36.1$ & 0.185 \\
\hline HDL (mg/dl) & $41.7 \pm 3.6^{\star \star \star *}$ & $35.6 \pm 7.6$ & $35.4 \pm 6.0$ & 0.001 \\
\hline Fasting glucose & $85.3 \pm 7.9^{\#}$ & $102.5 \pm 14.5$ & $96.9 \pm 11.3$ & 0.007 \\
\hline TOS ( $\mu$ mol H $\mathrm{H}_{2} \mathrm{O}_{2}$ Equiv. /L) & $6.40 \pm 1.09^{\# \#}$ & 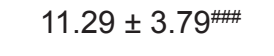 & $8.29 \pm 2.03$ & $<0.001$ \\
\hline TAC (mmol Trolox Equiv. /L) & $1.58 \pm 0.07^{\dagger}$ & $1.26 \pm 0.13^{t \dagger}$ & $1.51 \pm 0.08$ & $<0.001$ \\
\hline $\mathrm{LOOH}\left(\mu \mathrm{mol}\right.$ tBLOOH$\left.{ }^{*} / \mathrm{L}\right)$ & $4.20 \pm 0.61^{t+t}$ & $6.58 \pm 1.61^{\pi}$ & $4.70 \pm 0.99$ & $<0.001$ \\
\hline OSI (Arbitrary Unit) & $4.14 \pm 0.76$ & $9.05 \pm 3.26$ & $5.49 \pm 1.33$ & $<0.001$ \\
\hline
\end{tabular}

tBLOOH= terty buthyl hydroperoxide, BMI=Body mass index, DBP=diastolic blood pressure, DM=Diabetes mellitus, $\mathrm{HDL}=$ high density lipoprotein, hsCRP=high sensitive $c$ reactive protein, $L D L=$ low density lipoprotein, $S B P=s y s t o l i c$ blood pressure, TOS=total oxidant status, TAC=total antioxidant capacity, OSI=Oxidative Stress Index, $p=s i g n i f i c a n c e$. ${ }^{*} p<0.001$ vs. SX and NSX, " $p<0.001$ vs. NSX, ${ }^{* * *} p=0.001$ vs. SX and NSX, ${ }^{*} p<0.001$ vs. SX, $p=0.002$ vs. NSX, ${ }^{\#} p<0.001$ vs. SX, $p=0.022$ vs. NSX, ${ }^{\#} p<0.001$ vs. NSX, $\dagger p<0.001$ vs. $S X, p=0.041$ vs. NSX, ${ }^{\dagger \dagger} p<0.001$ vs. NSX, ${ }^{+\dagger} p<0.001$ vs. $S X, p<0.001$ vs. NSX, $p<0.001$ vs. $S X, p=0.048$ vs. NSX, $p<0.001$ vs. NSX 
Cardiac syndrome $X$ and NSX groups did not differ with regard to baseline medications taken before entry into the study, which included aspirin, nitrate, beta-blocking agents, angiotensin-convertingenzyme inhibitors and oral hypoglycemic agents ( $p>0.05$ for all).

In the CSX group $(n=33)$, there were significant correlation between OSI with age $(p=0.012)$, diastolic blood pressure $(p=0.03)$, hsCRP $(r ; 0.693$, $p<0.001)$ and the magnitude of ST depression ( $r$; $0.784, p<0.001$ ) (Table 2). In multiple linear regression analysis, which was performed by including the variables significantly correlated with OSI in bivariate correlation, OSI was independently correlated only with the magnitude of ST depression ( $B=0.606, p<0.001$ ) [Table 2]. Correlation between OSI with the magnitude of ST depression was demonstrated in Figure 1.

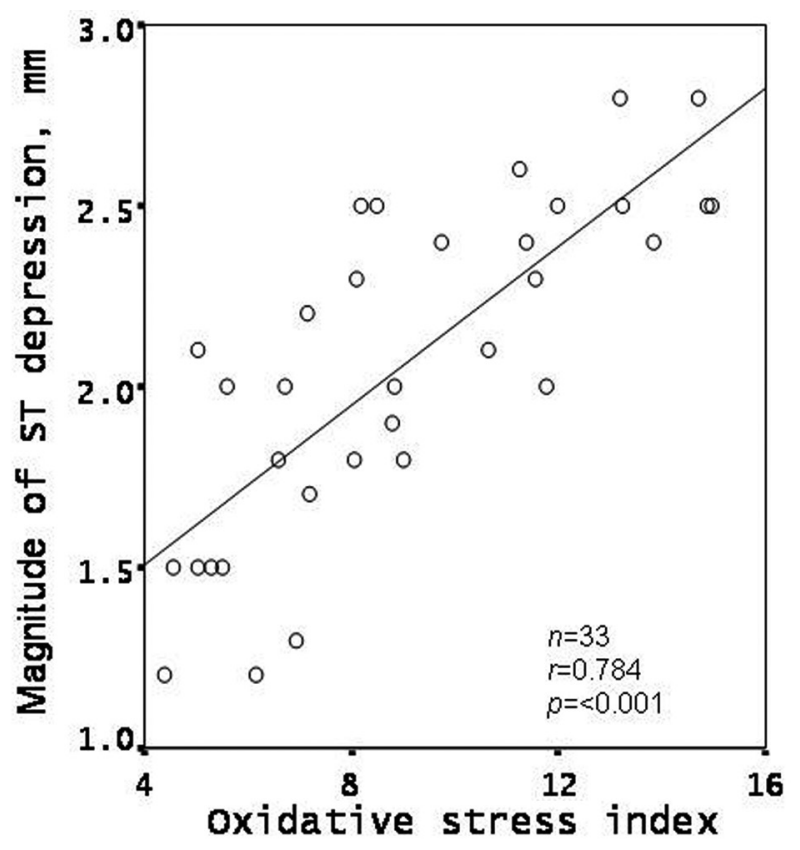

Figure 1. Relationship between oxidative stress index with the magnitude of ST depression

Table 2. Bivariate and multivariate relationships of the OSI to demographic, clinical, electrocardiographic and biochemical parameters in patients with CSX

\begin{tabular}{|c|c|c|c|c|}
\hline & \multicolumn{4}{|l|}{ OSI (Oxidative stress index) } \\
\hline & Pearson correlation coefficient & $p$ value & Standardized $B$ regression coefficients ${ }^{a}$ & $p$ value \\
\hline Age & 0.432 & 0.012 & 0.118 & 0.300 \\
\hline Body mass index $\left(\mathrm{kg} / \mathrm{m}^{2}\right)$ & 0.431 & 0.012 & 0.088 & 0.400 \\
\hline Triglyceride (mg/dl) & 0.001 & 0.996 & - & \\
\hline Total cholesterol (mg/dl) & 0.008 & 0.996 & - & \\
\hline $\mathrm{HDL}(\mathrm{mg} / \mathrm{dl})$ & 0.071 & 0.693 & - & \\
\hline LDL (mg/dl) & 0.005 & 0.979 & - & \\
\hline Fasting glucose & 0.250 & 0.161 & - & \\
\hline HsCRP (mg/dl) & 0.693 & $<0.001$ & 0.198 & 0.126 \\
\hline ST depression (mm) & 0.784 & $<0.001$ & 0.606 & $<0.001$ \\
\hline $\mathrm{SBP}(\mathrm{mmHg})$ & 0.141 & 0.434 & - & \\
\hline $\mathrm{DBP}(\mathrm{mmHg})$ & 0.378 & 0.030 & 0.200 & 0.265 \\
\hline
\end{tabular}

DBP, diastolic blood pressure; hsCRP, high sensitive $\mathrm{c}$ reactive protein; SBP, systolic blood pressure; Abbreviations as in Table; ${ }^{\text {a }}$ From multiple linear regression.

\section{DISCUSSION}

The main findings of the study are the following; ${ }^{1}$ the oxidative stress parameters (TOS, $\mathrm{LOOH}$ and OSI) of the CSX group were significantly higher than both NSX and control groups, ${ }^{2}$ TAC of the CSX group was significantly lower than both NSX and control groups, ${ }^{3}$ hsCRP levels of the CSX group were sig- nificantly higher than both NSX and control groups, ${ }^{4}$ there was a significant correlation between OSI with the magnitude of ST depression in multiple linear regression analysis.

The causes of increased oxidative stress may be various in patients with CSX. Presence of ischemia was proved in patients with CSX. ${ }^{9,10}$ Cannon et al. ${ }^{9}$ concluded that the pain and symptoms ex- 
perienced by patients with CSX were caused by myocardial ischemia, resulting from coronary microvascular dysfunction or microvascular angina. Abnormal subendocardial perfusion in CSX detected by cardiovascular magnetic resonance imaging seemed to support the presence of myocardial ischemia in patients with CSX..$^{10}$ Previous studies have suggested that repeated ischemia episodes and/or the atherosclerotic process might cause a persistent enhancement of reactive oxygen species generation by locally activated vascular cells. ${ }^{27,28}$ Our obtained results concerned with increased oxidative stress, in patients with CSX, may be related with the mentioned mechanism.

Subendocardial ischemia classically results in ST segment depression and T wave inversion. Thus, ST segment depression is related to ischemia. On the other hand, it has been shown that ischemia leads to increased oxidative stress. ${ }^{27,28}$ In our study, we found that there was a positive significant correlation between OSI with ST depression.

C-reactive protein, a marker of chronic inflammation, has been related to the inflammation that is seen in CSX.11,12 A systemic inflammation is also related to increased oxidative stress. In our study, hsCRP increased in patients with CSX compared with control group and NSX group. Increased chronic inflammation, which was reflected by hsCRP, might be a cause of increased oxidative stress in this patient group. In our study, also, there was an association between CRP and OSI levels in bivariate analysis.

Lekakis et al. ${ }^{13}$ found that flow-mediated dilatation was significantly lower in patients with CSX and those with coronary heart disease in comparison with controls, demonstrating impaired endothelium-dependent vasodilatation. Increased oxidative stress has been linked to impaired endothelial function in atherosclerosis and may play a role in the pathogenesis of cardiovascular events. ${ }^{13}$ In our study, we found that TOS, OSI, LOOOH increased and TAC decreased in the patients.

Different antioxidants and free radicals play important roles in hypertension and diabetes. ${ }^{29,30}$ In the current study, in CSX group, oxidative stress parameters were increased and TAC was decreased compared with control group and NSX groups. Oxidative stress parameters were significantly increased and TAC was markedly decreased in CSX group compared to control group. This may be thought to be due to the higher risk factor frequencies, i.e. HT and DM, in CSX group compared to control group. But, oxidative and antioxidative indicators were found to be significantly different in also
NSX group then the CSX group, though they have similar risk factor profiles. Therefore, it is concluded that oxidative stress was increased in CSX group due to above discussed factors rather than known risk factor such as age, gender, HT or DM.

Some studies concerning the effect of antioxidant therapies on atherosclerosis were published in previous literature. ${ }^{17,31}$ Self-selected supplementation of vitamin $E$ has been associated with reduced coronary events and atherosclerotic progression. ${ }^{17,31}$ The combined supplementation with vitamins $E$ and $C$ significantly inhibited the progression of coronary atherosclerosis in the Harvard IVUS trial. ${ }^{31}$ The supplementation with vitamin E plus and slow-release vitamin C, in ASAP study, reduced the progression of carotid atherosclerosis by $26 \%$, by $33 \%$ in men and $14 \%$ (not significant) in women. ${ }^{17}$ Also, angiotensin 1 receptor blockade had an antiatherosclerotic and antioxidative potential by the reduction of oxidative stress in the vessel wall. ${ }^{32} \mathrm{How}-$ ever, in some randomized clinical trials concerning with antioxidant therapy on atherosclerosis has been observed contradictory results. ${ }^{18,19}$ In present study, oxidative stress parameters were increased in CSX group. However, in patients with CSX, the effect of antioxidant therapy was not investigated in our study and previous studies. The effect of antioxidant therapy in patients with CSX should been investigated in future.

The most important limitation of our study was that sintigraphic assessment was not performed in patients with CSX. Coronary ischemia might be objectively determined by sintigraphy in patients demonstrating ST depression. Thus, relation between OSI and myocardial ischemia in patients with CSX could be more objectively demonstrated.

In conclusion, the present study demonstrated that oxidants increased, antioxidants decreased in patients with CSX, and increased oxidative stress might be related with ischemia of myocardium. Oxidative stress might play a role in the etiopathogenesis of the disease.

\section{REFERENCES}

1. Cannon RO, Epstein SE. "Microvascular angina" as a cause of chest pain with angiographically normal coronary arteries. Am J Cardiol 1988; 61 (15):1338-43.

2. Crea F, Lanza GA. Angina pectoris and normal coronary arteries: cardiac syndrome X. Heart 2004; 90 (4):457-63.

3. Dominguez-Rodriguez A, Garcia-Gonzalez M, AbreuGonzalez P. Cardiac syndrome X: diagnosis, pathogenesis and management. Am J Cardiovasc Drugs 2004; 4 (6):423-4. 
4. Bugiardini R, Pozzati A, Ottani F, Morgagni GL, Puddu $P$. Vasotonic angina: a spectrum of ischemic syndromes involving functional abnormalities of the epicardial and microvascular coronary circulation. J Am Coll Cardiol 1993; 22 (2):417-25.

5. Buus $\mathrm{NH}$, Bottcher M, Botker HE, Sorensen KE, Nielsen TT, Mulvany MJ. Reduced vasodilator capacity in syndrome $X$ related to structure and function of resistance arteries. Am J Cardiol 1999; 83 (2):149-54.

6. Egashira K, Inou T, Hirooka Y, Yamada A, Urabe Y, Takeshita A. Evidence of impaired endothelium-dependent coronary vasodilatation in patients with angina pectoris and normal coronary angiograms. N Engl J Med 1993; 328 (23): 1659-64.

7. Vane JR, Anggard EE, Botting RM. Regulatory functions of the vascular endothelium. N Engl J Med 1990; 323 (1): 27-36.

8. Osamichi S, Kouji K, Yoshimaro I, et al. Myocardial glucose metabolism assessed by positron emission tomography and the histopathologic findings of microvessels in syndrome X. Circ J 2004; 68 (3): 220-6.

9. Cannon RO III. Leon MB, Watson RM, Rosing DR, Epstein SE. Chest pain and 'normal' coronary arteries - role of small coronary arteries. Am J Cardiol 1985; 55 (3): 50B-60B.

10. Panting JR, Gatehouse PD, Yang GZ, et al. Abnormal subendocardial perfusion in cardiac syndrome $X$ detected by cardiovascular magnetic resonance imaging. N Engl J Med 2002; 346 (25): 1948-53.

11. Lanza GA, Sestito A, Cammarota G, et al. Assessment of Systemic Inflammation and Infective Pathogen Burden in Patients With Cardiac Syndrome X. Am J Cardiol 2004; 94 (1):40-4.

12. Vermeltfoort IA, Raijmakers PG, Riphagen II, et al. Definitions and incidence of cardiac syndrome $\mathrm{X}$ : review and analysis of clinical data. Clin Res Cardiol 2010; 99 (8):475-81.

13. Lekakis JP, Papamichael CM, Vemmos CN, Voutsas AA, Stamatelopoulos SF, Moulopoulos SD. Peripheral vascular endothelial dysfunction in patients with angina pectoris and normal coronary arteriograms. J Am Coll Cardiol 1998; 31 (3): 541-6.

14. Asbury EA, Creed F, Collins P. Distinct psychosocial differences between women with coronary heart disease and cardiac syndrome X. Eur Heart J 2004; 25 (19): 1695-701.

15. Halliwell B, Gutteridge JMC. Free radicals in biology and medicine. Third ed. Oxford: Oxford Science Publications; 2000: 617-24.

16. Young IS, McEneny J. Lipoprotein oxidation and atherosclerosis. Biochem Soc Transact 2001; 29 (2):35862.

17. Salonen RM, Nyyssonen K, Kaikkonen J, et al. Sixyear effect of combined vitamin $\mathrm{C}$ and $\mathrm{E}$ supplementation on atherosclerotic progression: the Antioxidant Supplementation in Atherosclerosis Prevention (ASAP) Study. Circulation 2003 25; 107 (7):947-53.
18. Witztum JL, Steinberg D. The oxidative modification hypothesis of atherosclerosis: does it hold for humans? Trends Cardiovasc Med 2001; 11 (3-4):93-102.

19. Tribble DL. AHA Science Advisory. Antioxidant consumption and risk of coronary heart disease: emphasis on vitamin $\mathrm{C}$, vitamin $\mathrm{E}$, and beta-carotene. A statement for healthcare professionals from the American Heart Association. Circulation 1999; 99 (4):591-5.

20. Erel O. A novel automated method to measure total antioxidant response against potent free radical reactions. Clin Biochem 2004; 37 (2):112- 9.

21. Aydın M, Selcoki Y, Nazlı Y, et al. Relationship between total antioxidant capacity and the severity of coronary artery disease. J Clin Exp Invest 2012;3 (1); 22-8.

22. Kosecik M, Erel O, Sevinc E, Selek S. Increased oxidative stress in children exposed to passive smoking. Int J Cardiol 2005; 100 (1):61-4.

23. Erel O. A new automated colorimetric method for measuring total oxidant status. Clin Biochem 2005; 38 (12):1103-11.

24. Gürbüz GD, Ulaş T, Paksoy F, et al. The effect of intravenous iron therapy on total antioxidant capacity in patients with iron deficiency anemia. J Clin Exp Invest 2011;2 (3); 287-91.

25. Arab K, Steghens JP. Plasma lipid hydroperoxides measurement by an automated xylenol orange method. Analytical Biochemistry 2004; 325 (1):158-63.

26. Demirbag R, Yilmaz R, Erel O, Gultekin U, Asci D, Elbasan Z. The relationship between potency of oxidative stress and severity of dilated cardiomyopathy. Can J Cardiol 2005; 21(10):851-5.

27. Stringer MD, Görög PG, Freeman A, Kakkar VV. Lipid peroxides and atherosclerosis. Br Med J 1989; 298 (6669):281-4.

28. Kovacs IB, Jahangiri M, Rees GM, Görög P. Elevated plasma lipid hydroperoxides in patients with coronary artery disease. Am Heart J 1997; 134 (3):572-6.

29. Kashyap MK, Yadav V, Sherawat BS, et al. Different antioxidants status, total antioxidant power and free radicals in essential hypertension. Mol Cell Biochem 2005; 277 (1-2):89-99.

30. Robertson RP, Harmon J, Tran PO, Tanaka Y, Takahashi H. Glucose toxicity in beta-cells: Type 2 diabetes, good radicals gone bad, and the glutathione connection. Diabetes 2003; 52 (3): 581-7.

31. Fang JC, Kinlay S, Beltrame J, et al. Effect of vitamins $C$ and $E$ on progression of transplant-associated arteriosclerosis: a randomized trial. Lancet 2002;359 (9312):1108-13

32. Rueckschloss U, Quinn MT, Holtz J, Morawietz H. Dose-dependent regulation of $\mathrm{NAD}(\mathrm{P}) \mathrm{H}$ oxidase expression by angiotensin II in human endothelial cells: protective effect of angiotensin II type 1 receptor blockade in patients with coronary artery disease. Arterioscler Thromb Vasc Biol 2002; 22 (11):1845-51. 